\title{
COMPARATIVE STUDY OF ORAL MISOPROSTOL AND INTRAVENOUS OXYTOCIN IN INDUCTION OF LABOUR IN PRELABOUR RUPTURE OF MEMBRANES AT TERM IN PRIMIGRAVIDA
}

\author{
S. Thangathai ${ }^{1}$, V. Kasthuri
}

${ }^{1}$ Associate Professor, Department of Obstetrics and Gynaecology, Government Thiruvarur Medical College.

${ }^{2}$ Associate Professor, Department of Obstetrics and Gynaecology, Government Thiruvarur Medical College.

\begin{tabular}{l}
\hline ABSTRACT \\
BACKGROUND \\
Prelabour Rupture of Membranes (PROM) is a common complication of pregnancy that has a major impact on maternal and \\
neonatal health. Induction of labour may help in reducing infectious morbidity.
\end{tabular}

AIM

To compare the efficacy of oral misoprostol and intravenous oxytocin in induction of labour in prelabour rupture of membranes at term in primigravida.

\section{STUDY DESIGN}

Total of 100 primigravida patients with term PROM were chosen and divided into two groups. Labour induction done with either oral misoprostol or intravenous oxytocin.

\section{MATERIAL AND METHODS}

50 women received $100 \mathrm{mcg}$ of oral misoprostol every $6 \mathrm{hrs}$. for a maximum of two doses. The other 50 women received intravenous oxytocin 2.5 units in $500 \mathrm{~mL}$ ringer lactate as an infusion. The induction delivery time, mode of delivery, Apgar scores, and third stage losses noted.

\section{RESULTS}

The mean induction delivery interval ( $8.3 \mathrm{hrs}$.) in oral misoprostol group is similar to intravenous oxytocin group (8.4 hrs.). Mode of delivery is also similar in both groups. Uterine tachysystole and hypertonus did not occur in both groups. In oral misoprostol, there was the incidence of systemic side effects.

\section{CONCLUSION}

Oral misoprostol offers an alternative treatment in induction of labour in term PROM. Oral misoprostol 100 mcg is similar to intravenous oxytocin in efficacy in such cases. Neonatal outcomes are not affected. Its cost effective and easy to administer. Can be stored at room temperature.

\section{KEYWORDS}

Misoprostol, Oxytocin, Prelabour Rupture of Membranes, Induction of Labour.

HOW TO CITE THIS ARTICLE: Thangathai S, Kasthuri V. Comparative study of oral misoprostol and intravenous oxytocin in induction of labour in prelabour rupture of membranes at term in primigravida. J. Evolution Med. Dent. Sci. 2016;5(67):4834-4838, DOI: $10.14260 /$ jemds/2016/1100

\section{INTRODUCTION}

Premature Rupture of Membranes (PROM) is defined as the spontaneous rupture of chorioamnion before the onset of uterine contractions. PROM is one of the most common complications of pregnancy that has a major impact on maternal and neonatal morbidity and mortality.[1] The incidence is around $8 \%$ for PROM at term. Infection is closely associated as an aetiological factor or an important sequence of PROM.

Misoprostol, a prostaglandin E1 (PGE1) analogue has been widely used as an agent for cervical ripening and labour induction. Oral misoprostol offers the theoretical advantage of avoiding infectious morbidity that maybe associated with placement of vaginal prostaglandins after rupture of membranes.[2]

Financial or Other, Competing Interest: None.

Submission 15-07-2016, Peer Review 06-08-2016,

Acceptance 13-08-2016, Published 22-08-2016.

Corresponding Author:

Dr. S. Thangathai,

Door No. 24,

State Bank Officers Colony,

Cantonment, Trichy.

E-mail: thangathais@yahoo.com

DOI: $10.14260 /$ jemds $/ 2016 / 1100$

\section{AIM}

1. To compare the efficacy of oral misoprostol and intravenous oxytocin in induction of labour in prelabour rupture of membranes at term in primigravida.

2. To determine the safety of oral misoprostol in induction of labour and to compare the same with intravenous oxytocin.

\section{MATERIALS AND METHODS}

Total of 100 primigravida patients with term PROM in our department at RMH, Thanjavur, were recruited for the study.

- Gestational Age (GA) was calculated from last menstrual period.

- Demonstration of leaking per vagina on speculum examination.

- Cervical assessment by Bishop's score.

The oral misoprostol group was assigned group 1.

The intravenous oxytocin group was assigned group 2 .

\author{
Inclusion Criteria \\ 1. Primigravida. \\ 2. Singleton gestation. \\ 3. Above 37 weeks of gestation. \\ 4. $\mathrm{PROM}<6 \mathrm{hrs}$.
}


5. Foetus in vertex presentation.

6. Reassuring CTG trace.

7. Bishop score 5-7.

8. No probable cephalopelvic disproportion.

9. Average age of the patient was 20-26 yrs.

\section{Exclusion Criteria}

1. Multiple pregnancy.

2. Previous uterine scar.

3. History of hypersensitivity to PG.

4. Prolonged PROM.

5. Non-assuring CTG.

6. Probable CPD.

7. Malpresentation.

8. Medical disorders-heart disease/asthma.

9. Vaginal/cervical infection.

\section{Case Preparation}

Initially after selecting the patients, taking history, a general and systemic examination of patient was done. Before starting on the drugs, the patients were informed. Pulse, BP, temperature recorded.

- $\quad$ A CTG trace was taken.

- A light fluid diet was given.

- Monitoring was done to rule out uterine activity.

- Bishop scoring and CPD assessment were done accurately in each case.

- Antibiotics were started at admission itself.

Group 1: The drug used was PGE1 (misoprostol tablets) orally. It is a $200 \mathrm{mcg}$ tablet. One half was given orally every $6 \mathrm{hrs}$. to a total of two doses. Patients were allowed to walk about freely. Foetal heart rate was recorded every 15 min in first stage and every $5 \mathrm{~min}$ in second stage. Maternal pulse rate, uterine contractility recorded regularly. Cervical factor was assessed after $6 \mathrm{hrs}$. and once the cervix was dilated more than $8 \mathrm{~cm}$ and the uterine contractions were ineffective, augmentation of labour with intravenous oxytocin as a drip started.

Group 2: The drug used was intravenous oxytocin as an infusion. After preparing the patient as in group 1, patient in left lateral position, intravenous oxytocin infusion ( 2.5 units of oxytocin in $500 \mathrm{~mL}$ of Ringer lactate) started at the rate of 8 drops/mt. Effective uterine contractions were watched for. The drip rate was increased by 8 drops every 30 minutes till effective uterine contractions (i.e., 3 contractions in 10 minutes, each lasting $30 \mathrm{sec}-45 \mathrm{sec}$ ) were set in. FHR, maternal pulse rate, uterine contractions were recorded periodically. Cervix was assessed after $4 \mathrm{hrs}$.

Data collected on mode of delivery, length of induction to delivery.

\section{Sepsis was ruled out if the following were absent. \\ a. Temperature more than 38 deg. C. \\ b. Maternal tachycardia more than $100 / \mathrm{min}$. \\ c. Foetal tachycardia more than $180 / \mathrm{min}$. \\ d. Uterine tenderness. \\ e. Foul smelling liquor.}

\section{OBSERVATIONS}

To study the efficacy of oral misoprostol as compared with intravenous oxytocin for induction of labour in primigravida with prelabour rupture of membranes at term, 100 cases were considered. Out of 100, 50 were given oral misoprostol, 100 mcg every 6 hours to a maximum of two doses. 50 were given intravenous oxytocin infusion. There was no significant difference in the mean, standard deviation, and $\mathrm{p}$ values between oral misoprostol and intravenous oxytocin groups based on age as shown in Table 1 . There is no significant difference between the two treatment groups in relation to age, gestational age, and initial Bishop score before intervention as seen in Table 2.

Table 3 shows that the mean values of induction delivery interval of oral misoprostol group and intravenous oxytocin are $8.3 \mathrm{hrs}$. and $8.4 \mathrm{hrs}$., respectively. Hence, the effect of the two drugs on IDI are similar. We did not encounter any case of tachysystole or hypertonus.

There was no significant difference in the outcome of mean induction to delivery interval between the two groups based on the initial Bishop's score. The P value was not significant as shown in Table 4 . There is no difference between the 2 drugs with respect to the mode of delivery as depicted in Table 5. About 19 (38\%) of patients needed the second dose of misoprostol and about six $(13.3 \%)$ of patients of the oral misoprostol group needed oxytocin augmentation. The patients in the IV oxytocin group needed the infusion until the end of delivery. We observe that in cases of oligohydramnios, response to induction is poor both with oral misoprostol and intravenous oxytocin.

\section{Indications for Caesarean Section}

Oral misoprostol: Failure to descend-2, foetal distress-1. Intravenous oxytocin: Failure to dilatation-2, foetal distress-1. of the 3 cases that went in for caesarean births in the oral misoprostol group, 2 of them had a short cord and in the other the cord was tightly round the neck twice. Liquor was clear in all the cases. Of the 3 cases that went in for caesarean births in the oxytocin group, 1 case had a meconium stained liquor.

The Table 6 shows that the mean values on IDI of the two groups are $8.4 \mathrm{hrs}$. and $8.25 \mathrm{hrs}$., respectively. Hence, there was no significant difference between the two groups, mean, standard deviation values between the oral misoprostol and intravenous oxytocin groups on IDI at 2-4 hrs. membrane rupture were similar. The mean values of IDI were 8.1 and 8.05 hrs., respectively. As seen in Tables 7, 8, and 9, the mean IDI between the oral misoprostol and intravenous oxytocin groups at 4-6 hrs. of membrane rupture are 7.83 and $8.35 \mathrm{hrs}$., respectively. Hence, there was no significant difference between the two groups of treatment on IDI based on the number of hours since membrane rupture. Though, there was more incidence of increased blood loss in $3^{\text {rd }}$ stage of labour in the intravenous oxytocin group, it was not of much significance. With regards to complications, 2 patients in oral misoprostol group had diarrhoea, one had nausea and vomiting, and 1 patient had shivering. 4 patients developed pyrexia in the oral misoprostol group. The temperature returned to normal in these patients after an intramuscular injection of paracetamol. There was no subsequent rise in temperature as seen in Table 10. In the oxytocin group, 3 patients had shivering soon after the infusion was started.

The infusion was discontinued and restarted after the shivering subsided using a fresh infusion set and IV fluid.

There was no evidence of uterine hyperstimulation in all the cases. Liquor was clear in all the cases except one. All the 
babies born in both the groups had good Apgar scores as seen in Table 11. None of the babies needed NICU admissions. The birth weight of the babies in the two groups were similar as shown in Table 12. No evidence of sepsis in the postnatal period.

\begin{tabular}{|c|c|c|}
\hline Oral Misoprostol & $\begin{array}{c}\text { Intravenous } \\
\text { Oxytocin }\end{array}$ & P-Value \\
\hline $22.04 \pm 1.49$ & $22.07 \pm 1.84$ & NS \\
\hline $\begin{array}{l}\text { Table 1: The Mean, Standard Deviation, and P Values } \\
\text { between Oral Misoprostol and Intravenous Oxytocin } \\
\text { Groups Based on Age }\end{array}$ \\
\hline
\end{tabular}

\begin{tabular}{|c|c|c|c|}
\hline Parameters & $\begin{array}{c}\text { Oral } \\
\text { Misoprostol }\end{array}$ & IV Oxytocin & P \\
\hline $\begin{array}{c}\text { Gestational } \\
\text { Age }\end{array}$ & $38.64 \pm 0.685$ & $38.22 \pm 0.985$ & NS \\
\hline $\begin{array}{c}\text { Initial Bishop } \\
\text { Score }\end{array}$ & $7.01 \pm 0.402$ & $6.76 \pm 0.511$ & \\
\hline
\end{tabular}

Table 2: The mean, Standard Deviation, and $P$ Values between Oral Misoprostol and Intravenous Oxytocin Groups on Gestational Age and Bishop's Score

\begin{tabular}{|c|c|c|c|}
\hline Group & Mean IDI & $\begin{array}{c}\text { Standard } \\
\text { Deviation }\end{array}$ & P value \\
\hline $\begin{array}{c}\text { Oral } \\
\text { misoprostol }\end{array}$ & $8.3 \mathrm{hrs}$. & \pm 1.3 & $\mathrm{NS}$ \\
\hline $\begin{array}{c}\text { Intravenous } \\
\text { oxytocin }\end{array}$ & $8.4 \mathrm{hrs}$. & \pm 1.2 & \\
\hline $\begin{array}{c}\text { Table 3: Comparison of Mean Induction Delivery } \\
\text { Interval between the Oral Misoprostol Group and } \\
\text { Intravenous Oxytocin Group }\end{array}$ \\
\hline
\end{tabular}

\begin{tabular}{|c|c|c|}
\hline Bishop's Score & Oral PGE1 & Oxytocin \\
\hline$<7 \mathrm{hrs}$. & $9.6 \mathrm{hrs}$. & $9.9 \mathrm{hrs}$. \\
\hline$>7 \mathrm{hrs}$. & $7.6 \mathrm{hrs}$. & $7.76 \mathrm{hrs}$. \\
\hline \multicolumn{3}{|c|}{ Table 4: Comparison of Mean IDI Time (Hours) of the } \\
Two Groups Based on Initial Bishop Score \\
\hline
\end{tabular}

\begin{tabular}{|c|c|c|}
\hline Mode of Delivery & Oral Misoprostol & IV Oxytocin \\
\hline Normal vaginal & 44 & 44 \\
\hline Instrumental & 3 & 3 \\
\hline LSCS & 3 & 3 \\
\hline \multicolumn{3}{|c|}{$\begin{array}{c}\text { Table 5: Comparison of the Mode of Delivery between } \\
\text { the Oral Misoprostol Group and Intravenous Oxytocin } \\
\text { Group }\end{array}$} \\
\hline
\end{tabular}

\begin{tabular}{|c|c|c|c|}
\hline 2 hrs. & $\begin{array}{c}\text { Statistical } \\
\text { Indices }\end{array}$ & $\begin{array}{c}\text { Oral } \\
\text { Misoprostol }\end{array}$ & IV Oxytocin \\
\hline & Mean & 495 & 506 \\
\hline & $\begin{array}{c}\text { Standard } \\
\text { deviation }\end{array}$ & 62 & 64 \\
\hline & 'p' value & $\mathrm{NS}$ & \\
\hline \multicolumn{2}{|c|}{$\begin{array}{c}\text { Table 6: Comparison of IDI between the Oral } \\
\text { Misoprostol and Intravenous Oxytocin Groups } \\
\text { According to Number of Hours Since Membrane Rupture }\end{array}$} \\
\hline
\end{tabular}

\begin{tabular}{|c|c|c|c|}
\hline 2-4 hrs. & $\begin{array}{c}\text { Statistical } \\
\text { Indices }\end{array}$ & $\begin{array}{c}\text { Oral } \\
\text { Misoprostol }\end{array}$ & IV Oxytocin \\
\hline & Mean & 490 & 503 \\
\hline & $\begin{array}{c}\text { Standard } \\
\text { deviation }\end{array}$ & 54 & 30 \\
\hline & P value & NS & \\
\hline
\end{tabular}

Table 7: Mean, Standard Deviation Values between the Oral Misoprostol and Intravenous Oxytocin Groups on IDI at 2-4 Hrs. Membrane Rupture

\begin{tabular}{|c|c|c|c|}
\hline 4-6 hrs. & $\begin{array}{c}\text { Statistical } \\
\text { Indices }\end{array}$ & $\begin{array}{c}\text { Oral } \\
\text { Misoprostol }\end{array}$ & IV Oxytocin \\
\hline & Mean & 470 & 501 \\
\hline & $\begin{array}{c}\text { Standard } \\
\text { deviation }\end{array}$ & 42 & 40 \\
\hline & P value & $0.05 \mathrm{NS}$ & \\
\hline $\begin{array}{c}\text { Table 8: Mean, Standard Deviation Values between the } \\
\text { Oral Misoprostol and Intravenous Oxytocin Groups on } \\
\text { IDI At 4-6 Hrs. of Membrane Rupture }\end{array}$ \\
\hline
\end{tabular}

\begin{tabular}{|c|c|c|}
\hline $\begin{array}{c}\text { Amount of } \\
\text { Blood Loss }\end{array}$ & $\begin{array}{c}\text { Oral Misoprostol } \\
\text { Group }\end{array}$ & $\begin{array}{c}\text { IV Oxytocin } \\
\text { Group }\end{array}$ \\
\hline About $300 \mathrm{~mL}$ & 46 & 43 \\
\hline $400-500 \mathrm{~mL}$ & $1(2 \%)$ & $4(8 \%)$ \\
\hline $\begin{array}{c}\text { Table 9: Comparison of the Amount of Blood Loss in the } \\
\text { Third Stage of Labour Values between the Oral } \\
\text { Misoprostol and Intravenous Oxytocin Groups }\end{array}$ \\
\hline
\end{tabular}

The number of cases is 47 in each group as the remaining 3 underwent caesarean section in each group.

\begin{tabular}{|c|c|c|}
\hline Side Effects & $\begin{array}{c}\text { Oral Misoprostol } \\
\mathbf{N = 5 0}\end{array}$ & $\begin{array}{c}\text { IV Oxytocin } \\
\mathbf{N = 5 0}\end{array}$ \\
\hline $\begin{array}{c}\text { Nausea and } \\
\text { Vomiting }\end{array}$ & $1(2 \%)$ & - \\
\hline Diarrhoea & $2(4 \%)$ & - \\
\hline Shivering & $1(2 \%)$ & $3(6 \%)$ \\
\hline Fever & $4(8 \%)$ & - \\
\hline \multicolumn{3}{|c|}{ Table 10 } \\
\hline
\end{tabular}

\begin{tabular}{|c|c|c|}
\hline Apgar Score & Number of Cases & Number of Cases \\
\hline & Oral misoprostol & $\begin{array}{c}\text { Intravenous } \\
\text { oxytocin }\end{array}$ \\
\hline 9 & $46(92 \%)$ & $47(94 \%)$ \\
\hline 8 & $4(8 \%)$ & $3(6 \%)$ \\
\hline
\end{tabular}

Table 11: Comparison of the Apgar Scores of the Babies Born in the Study in the Two Groups

\begin{tabular}{|c|c|c|}
\hline Birth Weight & Oral Misoprostol & $\begin{array}{c}\text { IV Oxytocin } \\
\text { Group }\end{array}$ \\
\hline $2-2.5 \mathrm{~kg}$ & 5 & 3 \\
\hline $2.5-3 \mathrm{~kg}$ & 30 & 34 \\
\hline $3-3.5 \mathrm{~kg}$ & 12 & 10 \\
\hline Table 12: Comparison of the Birth Weight of the Babies \\
Born in the Two Groups \\
\hline
\end{tabular}

\section{DISCUSSION}

Prelabour rupture of membranes is a common indication for labour induction. ${ }^{[3,4,]}$ Induction of labour with prostaglandins offers the advantage of promoting both cervical ripening and myometrial contractility in the group of women who present with PROM and an unfavourable cervix.

Misoprostol is absorbed orally and vaginally. Following oral administration, this drug is absorbed quickly and then esterified to be converted to its active form misoprostol acid less than $90 \%$ of which remains bound to serum proteins. Concentration of this metabolite reaches its peak plasma levels approximately by next 30 minutes and declines rapidly (halflife 21 mins) thereafter.

Misoprostol is inexpensive, easily stored, needs no refrigeration, easy to administer.

Prostaglandin-induced cervical ripening occurs by collagen rearrangement and realignment, which is no different than the natural ripening of cervix during labour. PROM (premature rupture of membranes may occur because of a 
reduction in membrane strength or an increase in intrauterine pressure or both. The membranes may lose their strength because of the effect of bacterial proteases and other products of bacterial metabolism. The source of infection is bacteria normally present in the vagina or the cervix.

\section{Diagnosis of PROM}

\section{Visualisation of Amniotic Fluid in the Vagina}

The diagnosis of PROM is easily made when amniotic fluid is present in the vaginal vault. If no fluid is present, slight pressure on the uterus and gentle moving of the foetus may provoke leaking. Sometimes, it is useful to ask the patient to cough or strain down. Fluid for lab tests can be collected over the lower blade of the speculum before it comes into contact with the vaginal wall.

\section{Ultrasound Examination}

Ultrasound examination should not be used as the primary means of diagnosis of PROM. False positive findings may occur with oligoamnios resulting from causes other than PROM. False negative may occur in patients with discrete amniotic fluid losses. However, it should be assumed that PROM has occurred if ultrasound shows little or no fluid in the uterus. In contrast, the presence of a normal amount of fluid makes the diagnosis of PROM unlikely.

The absence of a pocket of fluid with a vertical diameter more than $2 \mathrm{~cm}$ is diagnostic of oligoamnios. The method most commonly used is the amniotic fluid index, the four quadrant technique that consists of measuring the vertical diameter of the largest pocket seen in each of the four quadrants of the uterus. The diameters are added to calculate the AFI.

The most important maternal and foetal problem associated with PROM is infection.[5] The overall incidence of chorioamnionitis ranges from $4.2 \%$ to $10.2 \%$. The diagnosis is clinical. It requires the presence of fever more than $100 \mathrm{deg}$. F or 37.8 deg. C. and at least two of the following. Maternal tachycardia, foetal tachycardia, uterine tenderness, foul odour of amniotic fluid, maternal leucocytosis.

The incidence of chorioamnionitic infection after PROM is related to the duration of the latent period between PROM and delivery of the foetus. Burchell found that $1.7 \%$ of his patients developed fever with $24 \mathrm{hrs}$. PROM 7.5\% between $24-48 \mathrm{hrs}$. and $8.6 \%$ beyond $48 \mathrm{hrs}$. The risk of postpartum infectious morbidity for the mother with amnionitis is lower than the risk of infection for her neonate. The first biophysical manifestation of impending infection in patients with PROM is the nonreactive NST (non-stress test) and absence of foetal breathing movements. The most common FHR abnormality is variable deceleration depicting umbilical cord compression caused by oligohydramnios.

\section{Oxytocin}

The most widely used method of labour induction. It is safe to start oxytocin at 2 to $2.5 \mathrm{mu} / \mathrm{min}$ and rise to $14-15 \mathrm{mu} / \mathrm{min}$ till a contraction frequency of 3 per $10 \mathrm{~min}$ is reached with each contraction lasting for more than 40 seconds. If not, then increase oxytocin dose in increments of 4 to $5 \mathrm{mu} /$ min every 3 min. up to a maximum of 30 to $40 \mathrm{mu} / \mathrm{min}$.

Suk Wai Nagai (2000) compared the uterine activity of oral misoprostol with oxytocin for labour induction in women presenting with prelabour rupture of membranes at term. Intrauterine pressure transducers were introduced one hour before induction of labour in both groups of women. For those treated with oral misoprostol, mean uterine activity reached a peak 6-8 hrs. after the medication. Increase in high amplitude uterine activity was observed in the first 1 to 2 hours and persisted for the rest of labour. In the oxytocin group, the mean uterine activity rose steadily and reached the peak at 10-12 hours after treatment.

Ziemen et al compared the absorption kinetics between oral and vaginal administration of misoprostol. The study showed that in women receiving oral misoprostol, plasma concentration of misoprostol rose quickly and peaked between 12.5 and 60 minutes after administration fell steeply by 120 minutes and remained low. These findings explain the rapid increase in uterine activity after an oral medication, but could not explain the persistence of uterine activity after a single dose oral misoprostol. He postulated that misoprostol may initiate the endogenous prostaglandins secretion, which simulate spontaneous onset of labour.

The study enrolled primigravida with singleton gestations in vertex presentations at or beyond 37 wks. gestations who had spontaneous rupture of membranes within the previous six hours and who were not in labour and had no cephalopelvic disproportion.

The primary outcome measure is the mean time from induction to vaginal delivery, which was similar in both groups (8.3 hrs. in oral misoprostol and $8.4 \mathrm{hrs}$. in intravenous oxytocin group). The secondary maternal outcomes were caesarean deliveries, number of doses of misoprostol used, and maternal infection.

There was no difference in the proportion of women who underwent caesarean delivery $(6 \%)$ in the oral misoprostol group and $6 \%$ in the intravenous oxytocin group). The incidence of LSCS seems less as cases of severe oligoamnios and prolonged PROM were avoided. Also, there was no trial of labour for minor CPD.

Only 38\% of women required a second dose of misoprostol, but continuous infusion of oxytocin was required until delivery in the oxytocin group. The initial rise in temperature in the misoprostol group that subsided after administration of paracetamol, not to recur, rules out chorioamnionitis and so the pyrexia is probably due to oral misoprostol itself.

The secondary neonatal outcomes included Apgar scores and colour of amniotic fluid.

The MisoPROM study (2003) Mozurkavich et al[6] was undertaken to determine whether the induction of labour with oral misoprostol will result in fewer caesarean deliveries $(100$ mcg of oral misoprostol given every $6 \mathrm{hrs}$. for a maximum of 2 doses).

The mean induction delivery interval was similar in both groups (11.9 hrs. in oral misoprostol and $11.8 \mathrm{hrs}$. in intravenous oxytocin group). The mean IDI of $8.3 \mathrm{hrs}$. in our study may be explained by initial Bishop score of 5-7 when compared to 3-4 in their study.

The Bishop score can be taken as an independent predictor of success for labour induction.[7] Effacement and dilatation being the most important aspects of Bishop score.

Amniotic fluid index is another deciding factor for induction of labour with either misoprostol or intravenous oxytocin.[8,9] In severe oligoamnios, there is increased incidence of failed induction. Also, the longer the duration of PROM, there is more incidence of uterine inertia due to 
comparatively decreased liquor and possibly more chances of setting in of chorioamnionitis.

The increased proportion of subjects $(20 \%)$ requiring caesarean section when compared to our study (6\%) maybe explained by the longer duration of membrane rupture of 12 hrs. There is no difference in the proportion of women who underwent caesarean delivery between the 2 groups just as in our study.

\begin{tabular}{|c|c|c|}
\hline Study & $\begin{array}{c}\text { Induction } \\
\text { Delivery Interval }\end{array}$ & \\
\hline & Oral misoprostol & IV oxytocin \\
\hline Joan et al & $12.26 \mathrm{hrs.} \pm 7.1$ & $9.7 \mathrm{hrs} . \pm 5.3$ \\
\hline Mozurkewich et al & $11.9 \mathrm{hrs}$. & $11.8 \mathrm{hrs}$. \\
\hline Ngai SW et al & $7.3 \pm 3.1 \mathrm{hrs}$. & $11.1 \pm 4.9 \mathrm{hrs}$. \\
\hline
\end{tabular}

Ngai SW et al[10] (2000) compared the labour pattern and uterine activity of oral misoprostol with oxytocin for labour induction in women presenting with prelabour rupture of membranes at term. $100 \mathrm{mcg}$ misoprostol orally every $4 \mathrm{hrs}$. to a maximum of 3 doses). The IDI, mode of delivery, and perinatal outcome were similar in both the groups like in our study. The relatively conservative $6 \mathrm{hrs}$. dosing interval of oral misoprostol chosen in our study may explain the mean IDI of $8.3 \mathrm{hrs}$. when compared to $7.3 \mathrm{hrs}$. in that study.

Shetty et al (2004) reported a randomised trial comparing oral misoprostol (100 mcg every $4 \mathrm{hrs}$. to a maximum of 5 doses if indicated) versus vaginal dinoprostone $3 \mathrm{mg}$ for labour induction in patients with intact membranes. The mean IDI was $28.4 \mathrm{hrs}$. in the oral misoprostol group and 2 women had uterine hyperstimulation in this group. The oral misoprostol in our study differs a little from this in its $6 \mathrm{hrs}$. dosing. Furthermore, the women in our study were confined to those presenting with ruptured membranes. Their response to exogenous prostaglandins maybe different from those with intact membranes.

Apart from easier administration, oral misoprostol has the advantage of an exact dose preparation. Misoprostol is inexpensive when drugs and staff costs are considered. It is less expensive when compared to intravenous oxytocin. Titration with oxytocin is associated with restriction of patients and a doctor or nurse is required for continuous assessment and dosage control.

- The mean induction delivery interval (8.3 hrs.) in oral misoprostol group is similar to intravenous group (8.4 hrs.). This suggests that oral misoprostol may offer similar efficacy to oxytocin in induction of labour after PROM at term.

- Oral misoprostol presents a similar safety profile to oxytocin, the traditional modality.

- Mode of delivery is also similar in both groups. Uterine tachysystole and hypertonus did not occur in both groups. Taking into account the cost of infusion, it appears that oral misoprostol is advantageous in management of term pregnancies with premature rupture of membranes.
- In oral misoprostol, there was the incidence of systemic side effects.

\section{CONCLUSION}

Oral misoprostol offers an alternative treatment in induction of labour in management of prelabour rupture of membranes in term pregnancies besides waiting for spontaneous onset of labour.

Oral misoprostol $100 \mathrm{mcg}$ is similar to intravenous oxytocin in efficacy and safety for induction of labour in term PROM. The mean induction to delivery interval is similar in both groups. Neonatal outcomes are not affected.

Cost effective. Easy to use. Can be stored at room temperature. Though there are systemic side effects, they do not warrant intensive treatment. Blood loss was similar in both groups. Postpartum period was uneventful.

\section{REFERENCES}

1. American College of Obstetricians and Gynaecologists. Premature rupture of membranes. ACOG practice bulletin No. 1. Washington, DC: American College of Obstetricians and Gynaecologists 1998.

2. Crane JM, Delaney T, Hutchens D. Oral misoprostol for premature rupture of membranes at term. Am J Obstet Gynaecol 2003;189(3):720-4.

3. Hannah ME, Ohlson A, Farine D, et al. Induction of labour compared with expectant management for prelabour rupture of membrane at term. $N$ Engl J Med 1996;334(16):1005-10.

4. Ozden S, Delikara MN, Avci A, et al. Intravaginal misoprostol vs. expectant management in premature rupture of membranes with low Bishop scores at term. Int. J Gynaecol Obstet 2002;77(2):109-15.

5. Ingemarsson I. Controversies: Premature rupture of membrane at term, no advantage of delaying induction more than 24 hrs. J Perinat Med 1996;24(6):573-9.

6. Mozurkewich E. Prelabour rupture of membranes at term: Induction techniques. Clin Obstet Gynaecol 2006;49(3):672-83.

7. American College of Obstetricians and Gynaecologists. Technical bulletin, No. 127. Washington DC: Induction of Labour 1995.

8. Butt KD, Bennett KA, Crane JM, et al. Randomised comparison of oral misoprostol and oxytocin for labour induction in term prelab or membrane rupture. Obstet Gynaecol 1999;94(6):994-9.

9. Nigam A, Singh VK, Dubay P, et al. Misoprostol vs. oxytocin for induction of labour at term. Int J Gynaecol Obstet 2004;86(3):398-400.

10. Ngai SW, Chan YM, Lam SW. Labour characteristics and uterine activity: misoprostol compared with oxytocin in women at term with prelabour rupture of membranes. BJOG 2000;107(2):222-7. 